\title{
Chemical compositions of essential oils of Amomum verum and Cinnamomum parthenoxylon and their in vitro biological properties
}

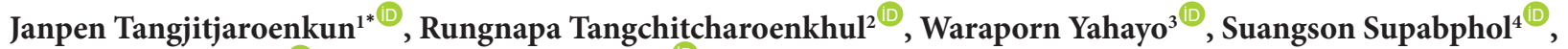 \\ Ruengrit Sappapan ${ }^{\mathbb{E}}$, Roongtawan Supabphol ${ }^{\mathbb{D}}$ \\ ${ }^{1}$ Department of Resources and Environment, Faculty of Science at Si Racha, Kasetsart University, Si Racha campus, Thailand \\ ${ }^{2}$ Graduate School, Suan Dusit University, Thailand \\ ${ }^{3}$ Multidisciplinary Laboratory, Faculty of Medicine, Srinakarinwirot University, Thailand \\ ${ }^{4}$ Faculty of Medicine, Chulalongkorn University, Thailand \\ ${ }^{5}$ Bangkok Lab \& Cosmetic Co. Ltd., Thailand \\ ${ }^{6}$ Department of Physiology, Faculty of Medicine, Srinakharinwirot University, Thailand
}

\section{A R T I C L E I N F O}

Article Type:

Original Article

\section{Article History:}

Received: 20 October 2019

Accepted: 20 March 2020

\section{Keywords:}

Amomum verum

Cinnamomum parthenoxylon

Essential oil

Antimicrobial activity

Cytotoxicity

Antioxidant activity

\begin{abstract}
A B S T RA C T
Introduction: In eastern Thailand, Amomum verum and Cinnamomum parthenoxylon are native plants used by local communities for their medical and culinary properties. This study determined the chemical composition and biological activities of the essential oils from A. verum shoots (AVSEO) and C. parthenoxylon wood (CPW-EO).

Methods: Essential oils were extracted using hydro-distillation and analyzed using gas chromatography-mass spectroscopy (GC-MS). The antimicrobial activity was evaluated using the disc diffusion method and broth microdilution assay. The cytotoxic activity of the essential oils was assessed against the human prostate adenocarcinoma (DU145) cell line using 3-(4,5-dimethylthiazol2-yl)-2,5-diphenyltetrazolium bromide (MTT) assay. The antioxidant activity of the essential oils was determined using 2,2-diphenyl-1-picrylhydrazyl (DPPH) and 2,2'-azino-bis-(3-ethylbenzothiazoline6-sulfonic acid) (ABTS) radical scavenging assays. The expression of antioxidant genes in the DU145 cells was evaluated using quantitative real-time polymerase chain reaction (qRT-PCR).

Results: 1,8-Cineole was the main component in AVS-EO and CPW-EO with 84.38, and $45.65 \%$, respectively. AVS-EO had stronger antimicrobial activity than CPW-EO. The lowest minimum inhibitory concentration (MIC) and minimum microbicidal concentration (MMC) values of AVSEO against Candida albicans were 0.3125 and $2.5 \mathrm{mg} / \mathrm{mL}$, respectively. Both essential oils had timedependent and dose-dependent cytotoxic effects on the DU145 human prostate adenocarcinoma cells. CPW-EO had high antioxidant activity toward DPPH and ABTS radicals with $\mathrm{IC}_{50}$ values of $4.528 \pm 0.233$ and $0.045 \pm 0.007 \mathrm{mg} / \mathrm{mL}$, respectively. The two essential oils up-regulated glutathione peroxidase $(\mathrm{GPx})$ and glutathione reductase $(\mathrm{GRx}) \mathrm{mRNA}$ expression in the oxidative stress response of DU145 cells.

Conclusion: AVS-EO and CPW-EO might be added as natural ingredients in food or dietary supplement products for the benefit of microbial and prostate cancer inhibition.
\end{abstract}

Implication for health policy/practice/research/medical education:

The essential oils of A. verum shoot (AVS-EO) and C. parthenoxylon wood (CPW-EO) had significant antimicrobial, antioxidant and cytotoxic properties. Consequently, they might be used as potential natural agents for the treatment of infectious diseases and prostate cancer.

Please cite this paper as: Tangjitjaroenkun J, Tangchitcharoenkhul R, Yahayo W, Supabphol S, Sappapan R, Supabphol R. Chemical compositions of essential oils of Amomum verum and Cinnamomum parthenoxylon and their in vitro biological properties. J Herbmed Pharmacol. 2020;9(3):223-229. doi: 10.34172/jhp.2020.29.

\section{Introduction}

Thailand is rich in plant biodiversity. The geographical features in eastern Thailand contain short mountain ranges alternating with small river basins (1). The conditions of the soil and climate have made this area well known as a major source of herbs and spices. Some plant species have been used in traditional medicine that reflects the local wisdom pass down from generation to generation through 
shared experience within the communities. Amomum verum Blackw. and Cinnamomum parthenoxylon Meisn. are native plants used by local communities for their medical and culinary properties. A. verum known as 'Cardamom' is a spice of the Zingiberaceae family. The leaves are alternate with an acute leaf apex. The flowers have small yellow petals. The fruits are a subspherical shape with three locules and have been used as a spice (2). Its essential oil has been used in flavoring agents. The fresh shoots and unripe fruits are served with various types of chili paste ('nam prick' in Thai). The fruit is used to treat stomach diseases, digestive disorders and flatulence (3). Many studies have reported on the isolation and characterization of chemical constituents from the fruit of this plant. The main constituents in the fruit are essential oils, namely 1,8-cineole, $a$-pinene, and a-terpinene. In addition, two novel compounds: (7S)-p-cymene-2,7,8triol and $(3 R, 4 R, 6 S)$ - $p$-menth-1-ene-3,6,10-triol are found in the ethanol extract of $A$. kravanh fruit (4). Furthermore, its essential oil has antibacterial activity against Bacillus subtilis and Escherichia coli (5).

Cinnamomum parthenoxylon is a medium-sized evergreen tree growing to $30 \mathrm{~m}$ in height belonging to the family Lauraceae. The leaves are alternate and are elliptic-ovate in shape. The inflorescence is axillary or in a pseudo terminal panicle. The flowers occur in small white or yellowish clusters at the top of the stem. The fruit is small and spherical in shape and unripe fruit is green, becoming black when fully ripe. The leaves and bark are used as spices and their essential oil could be used as a flavoring agent in food and beverages (6). C. parthenoxylon is also used in indigenous medicine for the treatment of various disorders including flatulence and as a heart tonic and for stomach problems (7). Safrole is the main component, consisting of approximately $99.8 \%$ of the leaf essential oil. It can inhibit the growth of Candida albicans with an MIC value of $0.063 \% \mathrm{v} / \mathrm{v}$ (8). The root oil showed potent activity against Streptococcus mutans (MIC $0.01 \mathrm{mg} / \mathrm{mL})$, C. albicans and dermatophytes $(0.5-1.0 \mathrm{mg} /$ $\mathrm{mL}$ ) and Bacillus subtilis (MIC $2 \mathrm{mg} / \mathrm{mL}$ ). The methanol extract of the heartwood showed moderate activity, with an inhibition zone $>10 \mathrm{~mm}$, against the phytopathogenic fungus, Gloeophyllum trabeum, using disc diffusion assay (9).

In eastern Thailand, the fresh shoots of $A$. verum are widely used in curry dishes and the aromatic wood of $C$. parthenoxylon can be used to treat illnesses or to build furniture. In addition, the literature survey revealed that there have been very few studies on the essential oil from either $A$. verum shoots or C. parthenoxylon wood. The present study aimed to characterize the essential oil in the A. verum shoot (AVS-EO) and the essential oil in the $C$. parthenoxylon wood (CPW-EO) along with their antimicrobial, cytotoxic and antioxidant properties.

\section{Material and Methods}

Plant materials

Fresh $A$. verum shoots were collected from a garden in Soi Dao district, Chantaburi province, Thailand. Fresh wood from C. parthenoxylon was obtained from a tropical rainforest in Khao Saming district, Trat province, Thailand. The plants were identified as A. verum Blackw. and C. parthenoxylon Meisn. by a forestry technical officer (Mr. Sukid Rueangruea and Mr. Manoop Poopath) at the Bangkok Forest Herbarium (BKF), Department of National Parks, Bangkok, Thailand. The voucher specimen numbers were recorded as BKF No.194332 for A. verum and BKF No.194296 for C. parthenoxylon.

\section{Essential oil extraction}

The shoots of $A$. verum were chopped into small pieces and hydro-distillated in a Clevenger-type apparatus. The essential oils were separated and dehydrated using anhydrous sodium sulfate $\left(\mathrm{Na}_{2} \mathrm{SO}_{4}\right)$, weighed and kept at $4^{\circ} \mathrm{C}$ until further analysis. The air-dried wood of C. parthenoxylon was powdered in an electric blender and a branch-shredding machine. The powdered wood was distillated and then went through the same process applied to the A. verum shoots to obtain the essential oil.

Gas chromatography-mass spectroscopy (GC-MS) analysis The analysis of GC-MS was performed on an Agilent GC6890N equipped with a 5973 mass spectrometer and an HP-5MS capillary column $(30 \mathrm{~m} \times 0.25 \mathrm{~mm} ; 0.25 \mathrm{~m}$ film thickness) (Santa Clara, CA, USA). The helium carrier gas was set a constant flow rate at $1.2 \mathrm{~mL} / \mathrm{min}$. Split injection $(20: 1)$ was used in an injection port at $230^{\circ} \mathrm{C}$. The program began with an oven temperature at $50^{\circ} \mathrm{C}$ for 5 minutes, increasing at $4^{\circ} \mathrm{C} / \mathrm{min}$ up to $230^{\circ} \mathrm{C}$. The mass spectra (MS) detection was performed in the electron ionization (EI) mode, $(70 \mathrm{eV})$, with a scan mode range of 40-400 amu. The identification of volatile components was confirmed by comparing their mass spectrum with the Wiley $7 \mathrm{n}$ mass spectral library (10).

\section{Microbial strains}

The test organisms used to test the antimicrobial activity of essential oils against three Gram-positive bacteria (Bacillus subtilis ATCC 6633, Staphylococcus aureus ATCC 25923 and Staphylococcus saprophyticus ATCC 15305) and seven Gram-negative bacteria (Escherichia coli ATCC 25922, Pseudomonas aeruginosa ATCC 27853, Salmonella typhimurium ATCC 13311, Enterobacter cloacae ATCC 23355, Klebsiella pneumoniae ATCC 13883 and Proteus mirabilis DMST 8212) and one pathogenic fungus (Candida albicans ATCC 10231). The bacterial culture was maintained on Mueller-Hinton agar (MHA) at $37^{\circ} \mathrm{C}$ for 24 hours whereas C. albicans was cultured on Sabouraud dextrose agar (SDA) at $30^{\circ} \mathrm{C}$ for 48 hours. These microorganisms were obtained from the Department of 
Medical Science Thailand Culture Collection (DMST), Ministry of Public Health, Nonthaburi, Thailand.

\section{Screening of antimicrobial activity}

The disc diffusion method was used to evaluate the antimicrobial activity of the essential oils (11). The essential oils were emulsified into $1 \%(\mathrm{v} / \mathrm{v})$ Tween 80 to the test concentration. The bacterial suspension was adjusted using sterile saline to $0.5 \mathrm{McF}$ arland standard turbidity $\left(1.5 \times 10^{8} \mathrm{CFU} / \mathrm{mL}\right)$ and that of fungal suspension to $1.0 \times 10^{6} \mathrm{CFU} / \mathrm{mL}$. Then, $100 \mu \mathrm{L}$ of each suspension was spread on MHA for bacteria and on SDA for yeast. On the inoculated agar surface, an autoclaved paper disc $(6 \mathrm{~mm}$ in diameter) was loaded with $10 \mu \mathrm{L}$ of the essential oil (5 $\mathrm{mg} /$ disc). Discs containing $10 \mu \mathrm{L}$ of $1 \%$ Tween 80 were used as negative controls. The positive controls consisted of standard antibiotic discs of penicillin G (10 unit/disc), chloramphenicol $(30 \mu \mathrm{g} / \mathrm{disc})$ and ketoconazole $(50 \mu \mathrm{g} /$ disc). Then, the inoculated MHA plates were incubated at $37^{\circ} \mathrm{C}$ for 24 hours while the SDA plates were incubated at $30^{\circ} \mathrm{C}$ for 48 hours. After incubation, the diameter of the antimicrobial zone of inhibition around the impregnated disc was measured in millimeters. All experiments were repeated in triplicate.

Determination of minimum inhibitory concentration (MIC) and minimum microbicidal concentration (MMC) The MIC and MMC values were determined using the modified microdilution method with resazurin in 96well microplates, using Muller-Hinton broth (MHB) for bacteria and Sabouraud dextrose broth (SDB) for yeast (12). Serial dilutions of each essential oil with two-fold dilution steps starting from $0.039 \mathrm{mg} / \mathrm{mL}$ and up to 100 $\mathrm{mg} / \mathrm{mL}$ were made using $1 \%$ Tween 80 . Each well of the microplate included $60 \mu \mathrm{L}$ of the media, $20 \mu \mathrm{L}$ of diluted essential oil samples and $20 \mu \mathrm{L}$ of cell suspension at a concentration of $1.0 \times 10^{6} \mathrm{CFU} / \mathrm{mL}$. The final volume in each well was $100 \mu \mathrm{L}$. The positive controls were chloramphenicol for the bacteria and ketoconazole for the fungus, while sterile MHB and SDB media with $1 \%$ Tween 80 were respectively used as negative control for the bacteria and fungus. The bacterial microplates were incubated at $37^{\circ} \mathrm{C}$ for 24 hours whereas the yeast microplates were incubated at $30^{\circ} \mathrm{C}$ for 48 hours. After that, $10 \mu \mathrm{L}$ of the sterile aqueous solution of resazurin $(0.02 \%)$ was added to each well and re-incubated for 3 hours. A change in color of the resazurin from blue to pink indicated the growth of microorganisms. The lowest concentration of the essential oil with no change of resazurin color was defined as the MIC value for that individual essential oil. The MMC was determined by subculturing onto MHA plates (for bacteria) or SDA plates (for yeast) from each well with a concentration above the MIC that showed no visible growth. The plates were incubated at $37^{\circ} \mathrm{C}$ for 24 hours for bacteria and at $30^{\circ} \mathrm{C}$ for 48 hours for C. albicans. The
MMC values were recorded as the lowest dilution of the essential oils showing no cell growth on the agar plates. All experiments were conducted in triplicate and repeated three times on different days.

Cell culture

Human prostate adenocarcinoma cells (DU145) were kindly provided by Professor Thompson EW, Department of Surgery, St. Vincent's Institute, University of Melbourne, VIC, Australia. The cells were cultured as a monolayer in Dulbecco's modified Eagle's medium (DMEM) supplemented with $10 \% \mathrm{FBS}, 100 \mathrm{unit} / \mathrm{mL}$ penicillin and $100 \mu \mathrm{g} / \mathrm{mL}$ streptomycin. The cells were maintained at $37^{\circ} \mathrm{C}$ in a humidified atmosphere containing $5 \% \mathrm{CO}_{2}$.

\section{Cell viability assay}

The cytotoxicity of essential oils was determined using colorimetric assay with 3-(4,5-dimethylthiazol-2-yl)-2,5diphenyltetrazolium bromide (MTT) reagent (13). Briefly, DU145 cells were seeded onto a 96-well culture plate at a density of 30000-60000 cells/well in serum-containing medium. Cells were grown to $80 \%$ confluency and treated with varying concentrations $(0-0.4 \mathrm{mg} / \mathrm{mL})$ of essential oils for 1,4 , and 7 days at $37^{\circ} \mathrm{C}$ in $5 \% \mathrm{CO}_{2}$. After treatment, the cells were washed twice with phosphate buffer saline (PBS). Then, $150 \mu \mathrm{L}$ of MTT $(1 \mathrm{mg} / \mathrm{mL})$ in serum-free DMEM was added to each well and incubated for 4 hours at $37^{\circ} \mathrm{C}$ in $5 \% \mathrm{CO}_{2}$. The supernatant was removed and the MTT formazan crystals were then solubilized with $150 \mu \mathrm{L}$ of dimethyl sulfoxide (DMSO) in each well. Absorbance was measured using a Biotek Synergy HT microplate reader (Winooski, VT, USA) at a wavelength of $570 \mathrm{~nm}$. The percentage cell survival compared to the untreated cells was determined. The viability of untreated cells was defined as $100 \%$. $\mathrm{IC}_{50}$ (the concentration that inhibited $50 \%$ cell growth) was used to compare the cytotoxic activity. All tests were done in triplicate and each test was carried out independently three times.

Free radical scavenging activity

The free radical scavenging activity of essential oils was determined according to the method described by Tangjitjaroenkun et al (14). The essential oils were dissolved in absolute ethanol at different concentrations. Each sample of essential oil $(250 \mu \mathrm{L})$ was mixed with 250 $\mu \mathrm{L}$ of freshly prepared ethanolic solution of DPPH (2.4 $\mathrm{mg}$ in $100 \mathrm{~mL}$ ethanol). Ethanol and synthetic antioxidant (butylated hydroxytoluene, BHT) were used as negative and positive controls, respectively. After 30 minutes of incubation at room temperature, the reaction mixture absorbance was measured at $520 \mathrm{~nm}$ using a UV-visible spectrophotometer. The percentage inhibition of DPPH radical scavenging activity was determined using the equation: 
$\%$ inhibition $=\left[\left(\mathrm{A}_{\text {blank }}-\mathrm{A}_{\text {sample }}\right)\right] / \mathrm{A}_{\text {blank }} \times 100$

where $\mathrm{A}_{\text {blank }}$ and $\mathrm{A}_{\text {sample }}$ are the absorbance of the negative control and the test essential oils, respectively. The $\mathrm{IC}_{50}$ value was calculated using the plotted graph between the percentage of DPPH radical scavenging capacity and the different concentrations of essential oil and BHT. All samples were tested in triplicate.

Trolox equivalent antioxidant capacity assay

The capacity of essential oils was determined according to Tangjitjaroenkun et al with the following slight modifications (14). 2,2'-Azino-bis(3ethylbenzothiazoline-6-sulphonic acid) radical cation (ABTS $^{\circ+}$ ) was generated by the reaction of $14 \mathrm{mM}$ ABTS aqueous solution with $5 \mathrm{mM}$ potassium persulfate $\left(\mathrm{K}_{2} \mathrm{~S}_{2} \mathrm{O}_{8}\right)$ solution; the mixture was incubated in the dark at room temperature for 12-16 hours. The $\mathrm{ABTS}^{\bullet+}$ solution was diluted with deionized water to obtain an absorbance value of $0.80 \pm 0.05$ at a wavelength of $734 \mathrm{~nm}$. Then, the ABTS $^{*+}$ solution was mixed with each diluted essential oil, or Trolox standard solution at various concentrations. All tests were analyzed using at least three independent replicates. After 1 minute of reaction, the absorbance of the resulting solution was recorded at a wavelength of $734 \mathrm{~nm}$ against a water blank. The results were calculated as $\mathrm{IC}_{50}$ values and compared with the standard Trolox in terms of Trolox equivalent antioxidant capacity (TEAC). The antioxidant activity was presented as $\mu \mathrm{M}$ Trolox/g essential oil.

\section{Gene expression of antioxidant enzymes}

Healthy DU145 cells were divided into two groups (the control and the treatment) with different concentrations of essential oils $(0.00-0.20 \mathrm{mg} / \mathrm{mL})$ for 7 days at $37^{\circ} \mathrm{C}$ in humidified air with $5 \% \mathrm{CO}_{2}$. Total cellular RNA samples from control and treated cells were extracted using TRIzol reagent according to the manufacturer's instructions (Invitrogen, Carlsbad, CA, USA). The concentration and purity of the extracted RNA were determined based on the absorbances at 260 and $260 \mathrm{~nm} / 280 \mathrm{~nm}$ ratios, respectively. Then, $50 \mu \mathrm{g}$ of RNA from each sample was transcribed to cDNA using a SuperScript RT kit (Invitrogen, USA) according to the manufacturer's instruction.

qRT-PCR for catalase (CAT), superoxide dismutase (SOD), glutathione peroxidase $(\mathrm{GPx})$ and glutathione reductase (GRx) mRNA expression were performed using SYBR green assay (Roche Diagnostics, Penzberg, Germany) on a $\mathrm{C} 100^{\mathrm{TM}}$ Thermo Cycler detection system (Bio-Rad, Hercules, CA, USA). All primers are listed in Table 1. The real time PCR reaction was carried out in a final volume of $20 \mu \mathrm{L}$ containing $10 \mu \mathrm{L}$ of SYBR Green Master Mix, $0.8 \mu \mathrm{L}$ of each primer, $1 \mu \mathrm{L}$ of cDNA and 8.2 $\mu \mathrm{L}$ of nuclease free water. The PCR conditions were set up as: initial DNA denaturation of $95^{\circ} \mathrm{C}$ for 10 minutes, followed by 40 cycles of denaturation at $95^{\circ} \mathrm{C}$ for 15 seconds, annealing and extension at $59^{\circ} \mathrm{C}$ for 1 minute (15). The relative quantification of gene expression was calculated according to the $2^{-\Delta \Delta \mathrm{CT}}$ method. The expression level of the antioxidant genes was normalized according to the expression of the glyceraldehyde-3-phosphate dehydrogenase (GAPDH) gene. The reactions for each sample were performed in triplicate. The antioxidant gene expression was reported as the mean \pm standard deviation (SD) from three independent amplifications.

\section{Statistical analysis}

All statistical analyses in this study were performed using the SPSS software package, version 23.0 (IBM Corp., Armonk, NY, USA). The data, expressed as mean \pm SD, were analyzed using one-way ANOVA and Turkey's multiple comparison tests and $P<0.05$ was considered statistically significant.

\section{Results}

Chemical composition of the essential oils

Fresh shoots of $A$. verum and dried wood pieces of $C$. parthenoxylon were hydro-distillated and produced essential oil yields of $0.37 \%$ and $10.58 \%$ (w/w), respectively. The chemical composition of the essential oils was carried out using GC-MS and the results are shown in Table 2.

The main content in both essential oils was oxygenated monoterpene (86.72 and $77.49 \%$, respectively) and identified as 1,8 -cineol (84.38 and $45.65 \%$, respectively). Approximately $10 \%$ of monoterpene hydrocarbons was also found in AVS-EO and CPW-EO. Five compounds were identified in the AVS-EO representing $97.74 \%$ of the total oil, while 17 compounds were detected in CPW-EO.

Antimicrobial activity

The antimicrobial activity of the essential oils was qualitatively and quantitatively determined using disc

Table 1. Nucleotides sequence of PCR primers using in gene expression analysis

\begin{tabular}{lcc}
\hline Gene & Forward primer & Reverse primer $^{\prime}$ \\
\hline CAT & 5'-CCTGGAGCACAGCATCCAAT-3' & 5'-GAATGCCCGCACCTGAGTAA-3' \\
SOD & 5'-GAGACTTGGGCAATGTGACTG-3' & 5'-TTACACCACAAGCCAAACGA-3' \\
GPx & 5'-TGGACATCAGGAGAACTGTCAGA-3' & 5'-AGACAGGATGCTCGTTCTGCC-3' \\
GRx & 5'-AAGCGGGATGCCTATGTGAG-3' \\
GAPDH & 5'-AGTCCACTGGCGTCTTCACC-3' & 5'-TTGGGATCACTCGTGAAGGC-3' \\
\hline
\end{tabular}


Table 2. Gas chromatography-mass spectroscopy (GC-MS) analysis of essential oils of Amomum verum shoots (AVS-EO) and Cinnamomum parthenoxylon wood (CPW-EO)

\begin{tabular}{|c|c|c|c|}
\hline $\begin{array}{l}\text { Retention time } \\
\text { (min) }\end{array}$ & Component & AVS-EO (\%) & CPW-EO (\%) \\
\hline 8.22 & $\alpha$-Thujene & - & 0.28 \\
\hline 8.46 & $\alpha$-Pinene & - & 1.40 \\
\hline 10.08 & Sabinene & - & 2.33 \\
\hline 10.17 & $\beta$-Pinene & - & 1.00 \\
\hline 10.87 & $\beta$-Myrcene & - & 0.61 \\
\hline 11.32 & $\delta$-3-Carene & - & 1.30 \\
\hline 11.83 & $\alpha$-Terpinene & - & 0.91 \\
\hline 12.16 & $p$-Cymeme & 4.87 & 1.11 \\
\hline 12.32 & Limonene & 6.15 & - \\
\hline 12.44 & 1,8-Cineole & 84.38 & 45.65 \\
\hline 13.56 & $\gamma$-Terpinene & - & 1.37 \\
\hline 14.73 & $\alpha$-Terpinolene & - & 0.41 \\
\hline 16.00 & $\begin{array}{l}\text { trans- } p \text {-Mentha- } \\
\text { 2,8-dienol }\end{array}$ & 1.27 & - \\
\hline 16.86 & Camphor & - & 11.62 \\
\hline 18.14 & Terpinen-4-ol & - & 6.05 \\
\hline 18.67 & $\alpha$-Terpineol & 1.07 & 14.17 \\
\hline 22.12 & Safrole & - & 4.10 \\
\hline 24.46 & Eugenol & - & 0.50 \\
\hline 30.88 & trans-Nerolidol & - & 3.03 \\
\hline \multicolumn{4}{|c|}{ Grouped components (\%) } \\
\hline \multicolumn{2}{|c|}{ Monoterpene hydrocarbons } & 11.02 & 10.72 \\
\hline \multicolumn{2}{|c|}{ Oxygenated monoterpenes } & 86.72 & 77.49 \\
\hline \multicolumn{2}{|c|}{ Oxygenated sesquiterpenes } & - & 3.03 \\
\hline \multicolumn{2}{|l|}{ Benzonoids } & - & 4.60 \\
\hline \multicolumn{2}{|l|}{ Total identified } & 97.74 & 95.84 \\
\hline
\end{tabular}

$(\%)^{\mathrm{a}}$ : relative percentage obtained from peak area.

diffusion assay and the broth microdilution susceptibility test, respectively (Table 3).

The qualitative antimicrobial activities of AVS-EO and CPW-EO (5 mg/disc) were assessed by measuring the size of the inhibition zone resulting from the growth of the test microbial strains compared to the standard antibiotic discs. The inhibition zone diameters of AVS-EO and CPW-EO for the tested organisms were in the ranges 8.0-31.7 and 8.5-14.3 mm, respectively. The AVS-EO had antimicrobial effects against eight microorganisms, especially E. cloacae and C. albicans with inhibition zones of 31.7 and $18.2 \mathrm{~mm}$, respectively, and did not affect the growth of $P$. aeruginosa and P. mirabilis. The CPW-EO had a broad spectrum of activity against all tested microorganisms with high sensitivity to B. subtilis and E. cloacae.

The quantitative determination based on the MIC and MMC values of the essential oils produced the same trends as the qualitative analysis. AVS-EO had the lowest MIC and MMC to C. albicans, which was inferred from the fungistatic and fungicidal activities, while only bacteriostatic activity was found with reference to $E$. cloacae. For CPW-EO, the lowest MIC was found against

\section{E. cloacae at $1.25 \mathrm{mg} / \mathrm{mL}$.}

Cytotoxic activity

The in vitro cytotoxic activity of the essential oils from $A$. verum and C. parthenoxylon was evaluated in human prostate adenocarcinoma cells (DU145) using MTT assay. This assay was based on the activity of mitochondrial succinate dehydrogenase in living cells being able to cleave the tetrazolium rings of MTT and form dark blue formazan crystals (16). The amount of formazan product is directly proportional to the number of viable cells. Cells were treated with increasing concentrations of each essential oil from 0 to $0.40 \mathrm{mg} / \mathrm{mL}$ in culture medium for 1, 4 and 7 days. The cytotoxic effects of each essential oil on the growth of the DU145 were found to be dose- and time-dependent and were presented as the percentage of cell viability compared to the control group (Figure 1).

The $\mathrm{IC}_{50}$ values for the AVS-EO treatment for 1,4 and 7 days were $>0.40$, approximately 0.40 and $0.185 \pm 0.008$ $\mathrm{mg} / \mathrm{mL}$, respectively, while those of CPW-EO were $>0.40$, approximately 0.40 and $0.170 \pm 0.012 \mathrm{mg} / \mathrm{mL}$, respectively. The growth inhibition of concentration ranged up to 0.20 $\mathrm{mg} / \mathrm{mL}$ and was slightly different for the essential oils. A significant decrease was observed when the dose increased to $0.30-0.40 \mathrm{mg} / \mathrm{mL}$.

Antioxidant capacity of essential oils

In this study, the antioxidant capacity of the essential oils was evaluated using two test methods (DPPH and ABTS radical scavenging activities). The antioxidant activity of AVS-EO could not be tested using these two assays because the $\mathrm{IC}_{50}$ was more than $10 \mathrm{mg} / \mathrm{mL}$. These tests inferred a higher antioxidant activity for CPW-EO. The $\mathrm{IC}_{50}$ values of CPW-EO based on DPPH and ABTS were $4.528 \pm 0.233$ and $0.045 \pm 0.007 \mathrm{mg} / \mathrm{mL}$, respectively. The TEAC value of CPW-EO was $157.20 \pm 10.24 \mu \mathrm{M}$ trolox/g.

Gene expression of antioxidant enzymes

Both essential oils showed similar trends of antioxidant gene expression (Figure 2). After 7 days of incubation, SOD and CAT expressions were significantly downregulated in a dose-dependent manner. In contrast, GPx and GRx expressions were significantly up-regulated in the treated cells compared to the control.

\section{Discussion}

According to the reports by Feng et al and Diao et al in China, the oxygenated monoterpene (1,8-cineole) was found to be the main component in $A$. verum dried fruit oil. Our results showed that different parts of A. verum, specifically the shoots, also possessed 1,8 -cineole as the main component amounting to $84.38 \%(5,17)$. For $C$. parthenoxylon, Subki et al and Palanuvej et al found that safrole was the main content in leaves at more than $90 \%$ $(8,18)$. Our study is the first report mentioning the wood 
Table 3. Antimicrobial activity of essential oils of Amomum verum shoot (AVS-EO) and Cinnamomum parthenoxylon wood (CPW-EO) against tested microorganisms

\begin{tabular}{|c|c|c|c|c|c|c|c|c|c|c|c|c|c|c|c|}
\hline \multirow{2}{*}{ Microorganism } & \multicolumn{3}{|c|}{ AVS-EO } & \multicolumn{3}{|c|}{ CPW-EO } & \multicolumn{3}{|c|}{ Chloramphinicol $^{b}$} & \multicolumn{3}{|c|}{ Penicillin $\mathbf{G}^{\mathrm{b}}$} & \multicolumn{3}{|c|}{ Ketoconazole $^{b}$} \\
\hline & $\mathrm{DIZ}(\mathrm{mm})$ & MIC & MMC & $\mathrm{DIZ}^{\mathrm{a}}(\mathrm{mm})$ & MIC & MMC & $\mathrm{DIZ}^{\mathrm{a}}(\mathrm{mm})$ & MIC & MMC & $\mathrm{DIZ}^{\mathrm{a}}(\mathrm{mm})$ & MIC & MMC & $\mathrm{DIZ}(\mathrm{mm})$ & MIC & MMC \\
\hline B. subtilis ATCC 6633 & $12.05 \pm 0.21$ & 2.5 & $>20$ & $14.30 \pm 1.33$ & 10 & $>20$ & $24.90 \pm 0.61$ & 0.0078 & 0.5 & $24.15 \pm 0.26$ & NT & NT & NT & NT & NT \\
\hline S. aureus ATCC 25923 & $8.00 \pm 0.36$ & 1.25 & $>20$ & $8.50 \pm 0.68$ & 10 & $>20$ & $17.13 \pm 0.45$ & 0.0078 & 0.125 & $22.95 \pm 1.20$ & NT & NT & NT & NT & NT \\
\hline $\begin{array}{l}\text { S. saprophyticus ATCC } \\
15305\end{array}$ & $9.28 \pm 0.73$ & $>20$ & $>20$ & $11.93 \pm 0.83$ & 10 & $>20$ & $21.08 \pm 0.40$ & 0.0039 & 0.125 & $33.73 \pm 0.60$ & NT & NT & NT & NT & NT \\
\hline P. aeruginosa ATCC 27853 & $0.00 \pm 0.00$ & $>20$ & $>20$ & $11.57 \pm 0.95$ & $>20$ & $>20$ & $0.00 \pm 0.00$ & 0.0625 & 0.625 & $6.13 \pm 0.21$ & NT & NT & NT & NT & NT \\
\hline S. typhimurium ATCC 13311 & $6.98 \pm 0.17$ & 2.5 & $>20$ & 10.240 .57 & 5 & $>20$ & $26.07 \pm 0.97$ & 0.00195 & 0.125 & $17.48 \pm 0.19$ & NT & NT & NT & NT & NT \\
\hline E. cloacae ATCC 23355 & $31.70 \pm 0.42$ & 0.625 & $>20$ & 13.930 .76 & 1.25 & $>20$ & $42.57 \pm 0.67$ & 0.0078 & 0.125 & $38.33 \pm 0.21$ & NT & NT & NT & NT & NT \\
\hline K. pneumoniae ATCC 13883 & $12.70 \pm 0.26$ & 2.5 & $>20$ & $9.13 \pm 1.18$ & 5 & $>20$ & $12.70 \pm 0.26$ & 0.0078 & 0.125 & $34.53 \pm 0.50$ & NT & NT & NT & NT & NT \\
\hline C. albicans ATCC 10231 & $18.17 \pm 0.31$ & 0.3125 & 2.5 & $11.67 \pm 0.91$ & 5 & 10 & NT & NT & NT & NT & NT & NT & $17.17 \pm 0.40$ & 0.0025 & 0.0050 \\
\hline
\end{tabular}

DIZ: diameter of inhibition zone; MIC: minimum inhibitory concentration $(\mathrm{mg} / \mathrm{mL}) ; \mathrm{MMC}$ : minimum microbicidal concentration (mg/mL); $\mathrm{NT}$ : not tested.

${ }^{a}$ values are mean inhibition zone $(\mathrm{mm}) \pm \mathrm{SD}$ of three replicates; ${ }^{\mathrm{b}}$ positive control. 

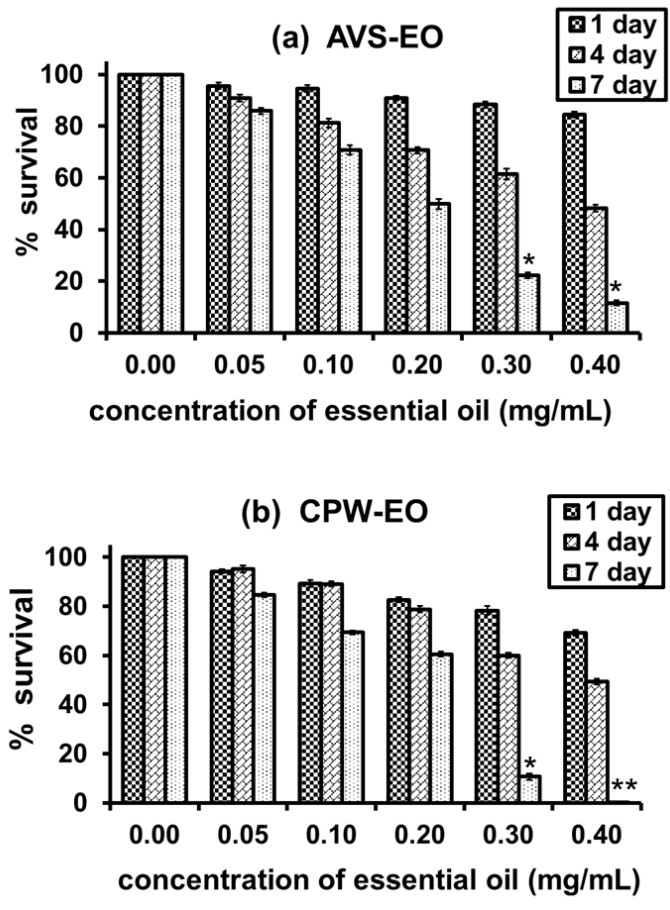

Figure 1. Cytotoxic effects of AVS-EO (a) and CPW-EO (b) in DU145 cells after incubation for 1, 4 and 7 days. Data are expressed as mean percentage in treated cells \pm standard deviation; ${ }^{*} P<0.05$, ${ }^{* *} P<0.01$ compared to the control group, $\mathrm{n}=3$.

essential oil from C. parthenoxylon containing 1,8-cineole as a main content at $45.65 \%$, instead of safrole. This can be used to confirm that the percentage and chemical constituents could be different in essential oils obtained from different parts of C. parthenoxylon. However, AVS$\mathrm{EO}$ and CPW-EO contained the same main compound, 1,8-cineole.

Regarding antimicrobial activity, AVS-EO and CPWEO were most effective at killing the fungus C. albicans and inhibiting the growth of gram-positive bacteria and gram-negative bacteria. AVS-EO was more active against the tested microorganisms than CPW-EO in terms of MIC values. The antimicrobial results may be related to the higher levels of 1,8-cineole in AVS-EO. Oxygenated monoterpenes in essential oil have been described as having antimicrobial activity in several reports. Our findings were in accordance with the results from Tabanca et al (19) who proved that the efficiency of a high amount of 1,8-cineole (over 85\%) in eucalyptus essential oil can inhibit fungal growth, especially C. albicans. Li et al (20) also reported the antibacterial action of 1,8-cineole on the integrity of the cell membrane and on morphological alterations of the cell wall of treated E. coli and S. aureus. These results support the antimicrobial properties of 1,8-cineole against gram-positive bacteria, gram-negative bacteria and a pathogenic yeast (C. albicans). Furthermore, the interaction between major constituents and other constituents of essential oil has been attributed to various


Figure 2. Gene expression of antioxidant enzyme genes, catalase (CAT), superoxide dismutase (SOD), glutathione peroxidase (GPx) and glutathione reductase (GRx), in DU145 exposed to AVS-EO (a) and CPWEO (b) for 7 days. The mRNA transcript levels were normalized relative to that of the glyceraldehyde-3-phosphate dehydrogenase (GAPDH) gene. Data are expressed the mean \pm standard deviation; ${ }^{*} P<0.05,{ }^{* *} P<0.01$ compared to control group, $n=3$.

degrees of antimicrobial efficacy (21).

Both essential oils displayed the same degree of toxicity against human prostate adenoma carcinoma cells in a time-dependent and dose-dependent fashion. There was clear cytotoxicity at high concentrations $(0.3$ and $0.4 \mathrm{mg} /$ $\mathrm{mL}$ ) after 7 days of treatment. The cytotoxic activity might have been related to the major compound, 1,8-cineole as this has been reported to suppress cell proliferation and induce apoptosis in the leukemia cell lines, Molt4B and HL-60, and in colorectal cancer cells $(22,23)$.

CPW-EO had better antioxidant properties than AVSEO. This might be due to the different constituents of the essential oils. However, both essential oils seemed to have a weak antioxidant property as shown in a previous study using DPPH and FRAP assay (24). These findings supported that the antioxidant activity was not related to the high content of 1,8-cineole. Previous studies reported that oxygenated monoterpene, especially thymol, carvacrol and $\alpha$-terpineol, possessed antioxidant activity in the essential oil from aromatic plants (25-26). This could explain how other compounds such as a-terpineol (14.17\%) could be responsible for the higher antioxidant activity of CPW-EO.

Additional studies on the mRNA levels of four antioxidant genes revealed the down-regulation of SOD and CAT, with up-regulation of GPx and GRx. The down-regulation of SOD and CAT may lead to a possible mechanism via the accumulation of intracellular free radicals. The up-regulation of GPx and GRx might be 
a cellular adaptation to use glutathione for free radical neutralization to protect the cell from oxidative stress. A previous study mentioned 1,8-cineole as a major compound in the essential oil of Salvia lavandulifolia, to regulate the cellular redox balance in astrocytes and to protect the astrocyte (U373-MG cell line) against $\mathrm{H}_{2} \mathrm{O}_{2}$ induced oxidative stress cellular damage (27). Based on this finding, it can be concluded that the main constituent of AVS-EO and CPW-EO, namely 1,8-cineole, may play an important role in intracellular redox regulation through the gene expression of antioxidant enzymes in DU145.

\section{Conclusion}

The chemical constituents of AVS-EO and CPW-EO were analyzed and identified using GC-MS. The high content of the oxygenated monoterpene, 1,8-cineole, might play a key role in antimicrobial activity, cytotoxicity and the regulation of the intracellular redox balance via upregulation to GPx and GRx and down-regulation to SOD and CAT.

\section{Acknowledgements}

The authors are grateful to the Kasetsart University Research and Development Institute (KURDI), Bangkok, Thailand and to the Faculty of Science at Sriracha, Kasetsart University, Thailand for financial support to this study.

\section{Authors' contributions}

JT and RS conceived and designed the experiment. JT, WY, SS performed the experiments. JT wrote the first draft of the manuscript. RT carried out the statistical analysis. All authors have read and approved the final manuscript.

\section{Conflict of interests}

The authors declare that there is no conflict of interest.

\section{Ethical considerations}

Ethical issues (including plagiarism, misconduct, data fabrication, falsification, double publication or submission and redundancy) have been carefully observed by authors.

\section{Funding/Support}

This research was financially supported by the Kasetsart University Research and Development Institute (KURDI) [grant number 20155810208000] and partially supported by the Faculty of Science at Sriracha, Kasetsart University [grant number 4/2016].

\section{References}

1. Soytong P, Janchidfa K, Phengphit N, Chayhard S, Perera $\mathrm{R}$. The effects of land use change and climate change on water resources in the eastern region of Thailand. Int J Agri Technol. 2016;12(7.1):1695-722.

2. Larsen K. A preliminary checklist of the Zingiberaceae of Thailand. Thai For Bull (Bot). 1996;24:35-49.
3. Yin H, Luo JG, Kong LY. Tetracyclic diterpenoids with isomerized isospongian skeleton and labdane diterpenoids from the fruits of Amomum kravanh. J Nat Prod. 2013;76:237-42.

4. Luo JG, Yin H, Kong LY. Monoterpenes from the fruit of Amomum kravanh. J Asian Nat Prod Res. 2014;16(5):471-5. doi: 10.1080/10286020.2014.906405.

5. Diao WR, Zhang LL, Feng SS, Xu JG. Chemical composition, antibacterial activity, and mechanism of action of the essential oil from Amomum kravanh. J Food Prot. 2014;77(10):1740-6. doi: 10.4315/0362-028X.JFP-14014.

6. Phongpaichit S, Kummee S, Nilrat L, Itarat A. Antimicrobial activity of oil from the root of Cinnamomum porrectum. Songklanakarin J Sci Technol. 2006;29(1):11-6.

7. Pongboonrord S. Mai-tet-muang-Thai. 1 st ed. Bangkok, Thailand: Kasem Bannakich Press; 1979.

8. Palanuvej C, Werawatganone P, Lipipun V, Ruangrungsi N. Chemical composition and antimicrobial activity against Candida albicans of essential oil from leaves of Cinnamomum porrectum. Thai J Health Res. 2006;20(1):6976.

9. Kawamura F, Ramle SFM, Sulaiman O, Hashim R, Ohara S. Antioxidant and antifungal activities of extracts from 15 selected heartwood species of Malaysian timber. Eur J Wood Wood Prod. 2011;69(2):207-12. doi: 10.1007/ s00107-010-0413-2.

10. Adams RP. Identification of essential oil components by gas chromatography/mass spectrometry. 4th ed. Carol Stream, Illinois, USA: Allured Publishing Corporation; 2007.

11. Tangjitjaroenkun J. Evaluation of antioxidant, antibacterial, and gas chromatography-mass spectrometry analysis of ethyl acetate extract of Streptomyces omiyaensis SCH2. Asian J Pharm Clin Res. 2018;11(7):271-6. doi: 10.22159/ ajpcr.2018.v11i7.25692.

12. Sarker SD, Nahar L, Kumarasamy Y. Microtiter-plate-based antibacterial assay incorporating resazurin as an indicator of cell growth, and its application in the in vitro antibacterial screening of phytochemicals. Methods. 2007;42(4):321-4. doi: 10.1016/j.ymeth.2007.01.006.

13. Tangjitjaroenkun J, Tangchitcharoenkhul R, Yahayo W, Supabphol R. In vitro antimicrobial and cytotoxic activities of mangrove actinomycetes from eastern Thailand. Chiang Mai J Sci. 2017;44(2):322-37.

14. Tangjitjaroenkun J, Supabphol R, Chavasiri W. Antioxidant effect of Zanthoxylum limonella Alston. J Med Plant Res. 2012;6(8):1407-14. doi: 10.5897/JMPR10.846.

15. Yahayo W, Supabphol A, Supabphol R. Supression of human fibrosarcoma cell metastasis by Phyllanthus emblica extract in vitro. Asian Pac J Cancer Prev. 2013;14(11):6863-7. doi: 10.7314/apjcp.2013.14.11.6863.

16. Edmondson JM, Armstrang LS, Martiner AO. A rapid and simple MTT-based spectrophotometric assay for determining drug sensitivity in monolayer cultures. J Tissue Cult Methods. 1998;11(1):15-7.

17. Feng X, Jiang ZT, Wangm Y, Li R. Composition comparison of essential oil extracted by hydrodistillation and microwave-assisted hydrodistillation from Amomum kravanh and Amomum compactum. J Essent Oil-Bear Plants. 2011;14(3):354-9. doi: 10.1080/0972060X.2011.10643945. 
18. Subki SYM, Jamal JA, Husain K, Manshoor N. Characterisation of leaf essential oils of three Cinnamomum species from Malaysia by gas chromatography and multivariate data analysis. Pharmacogn J. 2013(1);5:22-9. doi: $\quad$ 10.1016/j.phcgj.2012.12.004.

19. Tabanca N, Kirimer N, Demirci B, Demirci F, Baser KHC. Composition and antimicrobial activity of the essential oils of Micromeria cristata subsp. phyrgia and the enantiomeric distribution of borneol. J Agric Food Chem. 2001;49(9):4300-3. doi: 10.1021/jf0105034.

20. Li L, Li ZW, Yin ZQ, Wei Q, Jia RY, Zhou LJ, et al. Antibacterial activity of leaf essential oil and its constituents from Cinnamomum longepaniculatum. Int J Clin Exp Med. 2014;7(7):1721-7.

21. Tangjitjaroenkun J, Chavasiri W, Thunyaharn S, Yompakdee C. Bactericidal effects and time-kill studies of the essential oil from the fruits of Zanthoxylum limonella on multi-drug resistant bacteria. J Essent Oil Res. 2012;24(4):363-70. doi: 10.1080/10412905.2012.692907.

22. Murata S, Shiragami R, Kosugi C, Tezuka T, Yamazaki M, Hirano A, et al. Antitumor effect of 1,8-cineole against colon cancer. Oncol Rep. 2013;30(6):2647-52. doi: 10.3892/ or.2013.2763.
23. Moteki H, Hibasami H, Yamada Y, Katsuzaki H, Imai K, Komiya T. Specific induction of apoptosis by 1,8-cineole in two human leukemia cell lines, but not in a human stomach cancer cell line. Oncol Rep. 2002;9(4):757-60.

24. Zengin H, Baysal AH. Antibacterial and antioxidant activity of essential oil terpenes against pathogenic and spoilage-forming bacteria and cell structure-activity relationships evaluated by SEM microscopy. Molecules. 2014;19(11):17773-98. doi: 10.3390/molecules191117773.

25. Bicas JL, Neri-Numa IA, Ruiz ALTG, De Carvalho JE, Pastore GM. Evaluation of the antioxidant and antiproliferative potential of bioflavors. Food Chem Toxicol. 2011;49(7):1610-5. doi: 10.1016/j.fct.2011.04.012.

26. Miguel MG. Antioxidant activity of medicinal and aromatic plants. A review. Flavour Fragr J. 2010; 25:291-312. doi: 10.1002/ffj.1961.

27. Porres-Martínez M, González-Burgos E, Carretero ME, Gómez-Serranillos MP. Major selected monoterpenes a-pinene and 1,8-cineole found in Salvia lavandulifolia (Spanish sage) essential oil as regulators of cellular redox balance. Pharm Biol. 2015;53(6):921-9. doi: 10.3109/13880209.2014.950672. 